\section{Do conhecimento} físico e moral dos povos: iconografia e taxionomia na Viagem Filosófica de Alexandre Rodrigues Ferreira

\section{On the physical and moral \\ understanding of peoples: Iconography and Taxonomy in Alexandre Rodrigues Ferreira's \\ Philosophical Journey}

RAMINELLI, R.: 'Do conhecimento físico e moral dos povos: iconografia e taxionomia na Viagem Filosófica de Alexandre Rodrigues Ferreira'. História, Ciências, Saúde-Manguinhos, vol VIII (suplemento), 969-92, 2001.

A Viagem Filosófica produziu um vasto material iconográfico. Freire e Codina, os desenhistas da expedição, conceberam imagens que atuavam como taxionomia, destinada a classificar os grupos indígenas a partir da fisionomia, constituição corporal, moral e política. Essa taxionomia vincula-se tanto às normas científicas setecentistas quanto à lógica da colonização elaborada no período pombalino.

PALAVRAS-CHAVE: Viagem Filosófica, Alexandre Rodrigues Ferreira, Freire e Codina, naturalistas viajantes, iconografia, taxionomia.

RAMINELLI, R.: 'On the physical and moral understanding of peoples: Iconography and Taxonomy in Alexandre Rodrigues Ferreira's Philosophical Journey'.

História, Ciências, Saúde-Manguinhos, vol VIII (supplement), 969-92, 2001.

Ferreira's philosophical journey generated a large amount of iconographic material. Freire and Codina, the expedition artists, created images that intended to represent taxonomic categories for the classification of Indian groups, taking into consideration their physical features, as well as their moral and political constitution. This type of Taxonomy is related to both seventeenth century scientific rules and the colonial perspective built up during Pombal times.

KEYWORDS: Philosophical Journey, Alexandre Rodrigues Ferreira, Freire and Codina, travelling naturalists, Iconography, Taxonomy.

Ronald Raminelli 
$\mathrm{N}^{2}$ as expedições científicas, antes do advento da fotografia, os desenhos constituíam fonte valiosa de informações para os naturalistas. Textura, cores e formas anatômicas internas e externas das espécies eram preservadas graficamente, enquanto o material desidratado ou guardado em álcool era enviado em caixas aos gabinetes e herbários. Por intermédio das imagens, preservar-se-ia ainda tudo aquilo que não pudesse ser transportado: grandes animais, árvores, rochas, grutas e paisagens. A história natural, portanto, dependia dos diários, remessas e desenhos produzidos nas áreas de investigação. O viajante-naturalista era treinado para compor esse material e preservar a qualidade dos indícios colhidos ao longo da jornada (Stafford, 1984). A viagem filosófica comandada por Alexandre Rodrigues Ferreira percorreu as capitanias do Grão-Pará, Rio Negro, Mato Grosso e Cuiabá entre 1783 e 1792, produzindo centenas de estampas dedicadas aos três reinos da natureza. Os temas dos desenhos eram encomendados pelos naturalistas que, por sua vez, seguiam as diretrizes científicas elaboradas por Vandelli. Havia dois riscadores nessa viagem: José Joaquim Codina e Joaquim José Freire, autores dos desenhos analisados neste artigo.

Essa expedição forjou-se no Real Gabinete da Ajuda, que era composto por um horto botânico, museu de história natural, casa de risco e de gravura, além de biblioteca e cartório. Os riscadores eram previamente preparados para seguir nas viagens filosóficas. Para tanto, aperfeiçoavam a habilidade no desenho de seres vivos e paisagens. Em Coimbra, os alunos de história natural também recebiam aulas de risco, ensino indispensável para as funções que desempenhariam durante as investigações sobre os três reinos da natureza. Os desenhos eram concebidos em duas etapas: os riscadores iniciavam-nos durante as viagens, no terreno investigado, e posteriormente os finalizavam na Casa do Risco em Lisboa. Lá existiam condições para aperfeiçoar os desenhos e classificar as espécies segundo os ensinamentos de Lineu.

In loco, os artistas compunham desenhos aquarelados e a nanquim, destinados a representar aspectos geográficos e etnográficos, sem descuidar de plantas e animais. Os desenhos comporiam, mais tarde, gravuras, que ilustrariam a História natural das colônias, obra idealizada por Vandelli, que não veio a público. Havia, no entanto, interesse das autoridades portuguesas na publicação das estampas, pois preservaramse tanto os desenhos duplicados quanto as chapas de metal para reproduzi-los. A técnica de reproduzir imagens remonta ao século XV, período da invenção da imprensa e inovação nas artes gráficas. Mais tarde, elas tiveram enorme importância para os naturalistas, que divulgavam suas descobertas por intermédio dos livros (Rudnick, 1976, pp. 150-1). Naquele momento, uma vasta gama de objetos, desde máquinas, plantas até paisagens, foi reproduzida em xilogravuras, gravuras em cobre e metal. Por volta de 1800, uma nova transformação ocorreu nas artes gráficas, quando se tornou possível a impressão de aquarelas, gravuras em aço e litogravuras. Datadas desse período, as 
${ }^{1}$ Ver Alexandre Rodrigues Ferreira (Inventário geral e particulares de todos os produtos... Seção de Manuscritos da BNRJ, $21,1,10)$. As cifras variam entre os pesquisadores. Ângela Domingues (1992) menciona que Feire e Codina desenharam, in loco, cerca de 1.015 estampas de quadrúpedes, aves, peixes, insetos, plantas, alfaias de índios, paisagens e cartas geográficas. Edgar Cerqueira Falcão contabiliza 962 desenhos e aquarelas, em sua maioria, assinados pelos riscadores. Faria (1992b) inclui ainda 211 desenhos aquarelados encontrados no Museu Bocage, em Lisboa. estampas compostas por José Joaquim Codina e Joaquim José Freire, certamente, beneficiaram-se de tais avanços.

De Codina pouco se sabe. Freire teve importante papel na Casa do Risco do Museu da Ajuda. Antes, porém, freqüentou aulas de desenho na Fundição do Real Arsenal do Exército e, em 1783, desembarcou em Belém como riscador da expedição (Faria, 1992a). No inventário de 1794, Ferreira reuniu cerca de 2.670 desenhos, dos quais 1.015 eram originais, produzidos durante a viagem ao Pará. Para assegurar a preservação dessas imagens, faziam-se cópias. Ao retornar a Lisboa, a viagem filosófica reunia cerca de 544 cópias. Na Biblioteca Nacional do Rio de Janeiro, encontram-se 912 estampas, parte certamente copiada dos originais, encontrados no Museu Bocage em Lisboa. ${ }^{1}$

Vanzolini (1996, p. 200) considerou que a execução das estampas era de valor mediano. Os peixes foram muito bem representados, mas os mamíferos estão mal desenhados e identificados. Os desenhos de aves são "exemplares obviamente taxidermados, dobrados e comprimidos. Não fazem boa ilustração.” De modo geral, as pranchas permitem identificação das espécies e estão de acordo com a qualidade das produções européias da época. A flora é a parte mais representativa do acervo. No Museu Nacional do Rio de Janeiro, existem 668 estampas sobre a flora, enquanto na Biblioteca Nacional do Rio de Janeiro (BNRJ) esse reino está presente em 680 estampas inéditas. Levando-se em consideração as memórias, diários, herbários e estampas, há cerca de 3.900 referências a plantas amazônicas (Martinelli, 1992, p. 100), demonstrando o nítido interesse da expedição pela flora. Vale lembrar que a botânica era o principal ramo do conhecimento científico setecentista (Foulcault, s. d., p. 185). Além de ser alvo das ilustrações, as plantas e a agricultura, sobretudo, tornaram-se a base das reformas de caráter fisiocrático, que pretendiam restabelecer a economia, debilitada pela queda na produção de metais preciosos.

Nas estampas dedicadas aos índios, os riscadores demonstraram dificuldade em representar o corpo humano. Não estavam treinados a compor músculos, membros e troncos, mãos e pés de forma harmônica, traçar fisionomias diversificadas e expressar sentimentos. Essas formas anatômicas, presentes desde a Renascença nas gravuras européias, não foram empregadas para representar os índios da Amazônia. Os artistas não recorreram a esses clichês para compor os corpos. Essa característica repete-se nos riscos iluminados de Carlos Julião, que, como Freire, não recorreu às formas clássicas para compor corpos. Os desenhadores da história natural receberam, provavelmente, formação técnica na Fundição do Arsenal Real do Exército. Eles estavam, por certo, mais habilitados ao desenho técnico. Faria (1992a, p. 73) destaca ainda que as formas toscas dos índios devem-se às especificidades do desenho composto durante as viagens. Longe da Casa do Risco, os desenhistas executavam rapidamente as obras e enfrentavam a indisponibilidade dos índios em posar para os artistas. 
${ }^{2}$ No acervo da BNRJ/ Seção de Manuscritos (cód. 21,1,1A), as estampas não possuem legendas. Na publicação do Conselho Federal de Cultura (1971), as legendas foram acrescentadas, nem sempre com muito rigor. Por vezes, elas contrariam as legendas originais encontradas no Museu Bocage, em Lisboa.
Confrontando os acervos do Museu Bocage e da BNRJ, Miguel Faria (idem, p. 69) teceu algumas considerações em relação às imagens dedicadas ao gentio: os originais, em boa parte, estão assinados, o que não acontece com as cópias; os originais possuem legendas detalhadas, demonstrando conhecimento direto sobre o material representado, enquanto as cópias possuem legendas curtas. ${ }^{2}$ Os copistas, portanto, não se preocuparam em passar as legendas originais para as cópias; os originais não possuem aperfeiçoamento do plano de fundo. Nas cópias, no entanto, esse aspecto provoca uma sensação artificial de encenação.

\section{Da descrição}

A descrição científica tornou-se tema de debate entre os naturalistas do Setecentos. Para Buffon, não se podia definir uma espécie sem descrevê-la detalhadamente: era mais importante traçar imagens vivas dos diversos tipos de animais do que apenas identificá-los (Mayr, 1998, p. 210). O texto e a imagem eram, portanto, empregados para difundir os conhecimentos e avanços científicos. Nesse período, ocorreu uma subdivisão das tarefas descritivas. A relação texto/imagem era concebida como pleonástica ou excludente. Reaumur considerou a prancha como auxiliar da descrição. Os desenhos comunicavam mais rapidamente e transmitiam um conteúdo idêntico ao da descrição. "Entre a descrição textual e a prancha, há freqüentemente um tipo de 'texto-tampão', cuja função é comentar a figura, destacando o quanto ela confirma o que se diz para além da descrição" (Reynaud, 1990, p. 315). Concebida como confirmação, a imagem deveria ser, ao mesmo tempo, independente e redundante, sempre amparada pelo texto para servir como discurso científico.

Adanson, porém, concebeu a relação texto e imagem de modo excludente. As pranchas transmitiam informações que não estavam ao alcance da descrição textual. Textos e pranchas não eram redundantes, possuíam especificidades. As últimas estavam encarregadas de exprimir "qualidades essenciais", enquanto os textos deveriam ser curtos e enfatizar principalmente aspectos que a imagem não podia expressar. A escrita, portanto, deveria ater-se ao movimento, ao âmbito temporal e a outras sensações não visuais. Esse tipo de conhecimento foi denominado por Buffon como histórico. Os debates criaram, por conseguinte, uma cisão: descrição/história e retrato/quadro. A história opunha-se à descrição, pois estava encarregada de perceber o movimento (crescimento, interferências do clima etc.), ao passo que a descrição se concentrava nos aspectos estáticos. O retrato era concebido como percepção visual e estática, enquanto o quadro retratava o movimento.

Na defesa da descrição, Daubenton destacou que, longe de enquadrar o visível, a prancha interpretava-o, deformava-o, até que ela correspondesse à idéia do animal. Os naturalistas, enfim, consideraram 
a descrição arbitrária, destituída da objetividade defendida por Lineu. No Século das Luzes, a história natural promoveu o "objeto intermediário". As variadas formas de descrever não mais se interessariam pelo indivíduo excepcional, mas pelo exemplar, pela espécie. O protótipo não se confundiria com a realidade, mas sintetizaria características de um grupo.

A viagem filosófica seguiu esses princípios e dedicou pranchas à fauna, à flora e a grupos indígenas. As imagens estão acompanhadas de memórias que não podem ser analisadas separadamente. O texto escrito, por certo, fornece maior inteligibilidade à descrição visual. Nesta interseção, procurarei analisar os interesses científicos e coloniais dessa expedição pelo Amazonas.

Alexandre Rodrigues Ferreira produziu dezenas de memórias ao longo da viagem. As descrições procuram explorar os três reinos da natureza. Neste artigo, porém, tratarei apenas das memórias e estampas dedicadas às comunidades indígenas. Os Jurupixuna, Maué, Uerequena, Mura, Cambeba e Miranha constituem os principais grupos. Nesses relatos, o naturalista descreveu seus corpos, costumes, atividades produtivas e o convívio nem sempre pacífico entre índios e colonizadores. Freire e Codina contribuíram também para tornar conhecidos esses povos, desenhando e transformando em imagem algumas descrições textuais produzidas pelo naturalista. As memórias nem sempre são exaustivas. Alguns grupos foram apenas mencionados; outros, porém, receberam destaque. Os Mura, por certo, tornaram-se o alvo preferencial de observação. Considerados como "gentio do corso", eles causaram sérios prejuízos aos colonos e ao comércio de drogas do sertão no rio Madeira. Sua 'pacificação' era almejada pelos administradores coloniais, razão para o naturalista dedicar-lhes memórias e estampas. Os índios rebeldes de outras fronteiras também receberam destaque nas memórias. Os Guaikurú radicavam-se nas franjas do Império e manejavam bem os cavalos roubados dos espanhóis. Sua redução tranqüilizava a Coroa e minimizava a possibilidade de perda territorial. A descrição, portanto, possuía profundos vínculos com os interesses coloniais, como demonstram as instruções recebidas por Ferreira antes de partir para a América portuguesa.

Domenico Vandelli redigiu instruções pormenorizadas para as viagens filosóficas. Esse documento servia como norma científica para os naturalistas. Nele a fauna e a flora receberam enorme destaque, enquanto os costumes e organização social das comunidades visitadas tornaram-se item de menor valia. O conhecimento físico e moral dos povos estava imbricado com as atividades produtivas, demonstrando o interesse dos viajantes em verificar as potencialidades da agricultura e a capacidade produtiva da população. A agricultura e a horticultura, canoas, barcos, navios, bebidas, tecidos, armas e instrumentos musicais foram exaustivamente pormenorizados. Os naturalistas deveriam ainda descrever hábitos indígenas, sua estrutura, 
fisionomia e figura. Nos lugares povoados, teriam de produzir catálogo dos vivos e mortos; "se passam uma vida casta, ou dissoluta, servindose igualmente da monogamia, ou poligamia; se as mulheres são fecundas, ou estéreis; de que modo educam seus filhos" (Vandelli, 1779, p. 9, grifos no original). A descrição, portanto, estava imbuída de interesses coloniais, sem se esquivar dos avanços científicos.

Membro da Academia das Ciências, José António de Sá (1783, pp. 209, 210) também se preocupou com a descrição na viagem filosófica. Seu estudo, publicado em 1783, advertia sobre a brevidade e objetividade da narrativa. Os relatos deveriam ser concisos, evitando a superfluidade e redundância da palavra. Os excessos seriam evitados; do contrário, comprometer-se-ia o conhecimento das coisas: "não deixando nada que seja capaz de individuar, e especificar a cousa, de que se trata; em uma palavra, deve ter uma brevidade clara e uma extensão precisa”. Sá mencionou, igualmente, o risco e a pintura, empregados para os objetos que "a narração não for capaz de descrever perfeitamente, e com clareza.” Essas instruções estavam de acordo com os princípios da história natural setecentista, que procurou olhar para a natureza mais de perto e restringir voluntariamente o campo do conhecimento. Para Foucault (s. d., p. 195), não se tratava de retração da curiosidade, mas da disposição fundamental para o visível. Os naturalistas marcavam, portanto, identidades e diferenças, capazes de individualizar as espécies: "Conhecer aquilo que pertence exclusivamente a um indivíduo implica ter em mente a classificação ou a possibilidade de classificar o conjunto dos outros." As informações colhidas pelos naturalistas estavam profundamente imbricadas, eram parte de um sistema. Por essa razão, eles deveriam, sobretudo, marcar identidades e diferenças, em vez de se perderem na superfluidade da palavra.

Enfim, entre os naturalistas portugueses encontram-se alguns princípios básicos para a descrição: deveria ser textual e visual; caracterizava-se pela brevidade e objetividade; servia para individualizar as espécies; vinculava-se aos interesses coloniais e científicos. Essas premissas são de enorme interesse para a análise das estampas dedicadas aos índios.

\section{Iconografia e taxionomia}

Denominados genericamente de Tapuio (ou Tapuia), os índios da Amazônia eram da "classe dos mamíferos, 1ª ordem — dos quadrúpedes, 1ํㅡㄹivisão - dos terrestres unguiculados, I- gênero: 1 - Homo sapiens, Abá Mira - Homem 1ํㅡㄹ var. americanus, tapuia”. A partir da nomeação, Ferreira (1972, pp. 67-204) dissertou sobre a constituição física, moral e política dos povos amazônicos (rios Amazonas, Negro e Madeira). Nas observações sobre os mamíferos, buscava encontrar pontos coincidentes entre os americanos, mas sobretudo entre os Tapuio. Para 
tanto, o naturalista recorreu aos testemunhos de viajantes, cronistas e estudiosos da América, cruzando informações, verificando similitudes, com a finalidade de compor uma "figura americana". Nas demais memórias, percorreu as várias nações indígenas, particularizando-as, sem buscar explicações para costumes e idiossincrasias; limitava-se a descrevê-las nos aspectos visíveis e extraídos dos acontecimentos. Essas memórias não possuem forma homogênea, não receberam padronização. Os temas tornam-se superficiais ou detalhados conforme as particularidades e 'excentricidades' dos povos. Mas há temáticas recorrentes, como as deformidades físicas, as roupas, a produção de armas e utensílios, localização geográfica e história dos contatos com os europeus. As análises de Ferreira investiam, portanto, em dois campos: o geral (Tapuia) e o particular (as nações). Nas estampas, também se percebe esse duplo movimento.

As estampas da viagem filosófica pretendiam classificar as nações indígenas, criar uma identidade para cada uma delas. As imagens atuavam, por conseguinte, como taxionomias, identificando os aspectos anatômicos e culturais específicos de cada comunidade. Por intermédio de identidades e diferenças, o naturalista classificou-as pela fisionomia, "deformidade" anatômica, enfeite, vestimenta e capacidade produtiva. A descrição visual é, portanto, particularmente estática, dedicada sobretudo a pormenorizar os índios pelos aspectos externos e imediatos. Conforme os pressupostos buffonianos, a descrição histórica está ausente de quase todas as estampas. As alterações promovidas pelo tempo foram pouco retratadas na iconografia, mas tornam-se recorrentes nas memórias.

Para além da concepção estática, as estampas evidenciam os traços anatômicos semelhantes entre as nações. O fato pode, no entanto, ser entendido como falta de habilidade artística. Inexperientes em retratar a anatomia humana, os riscadores repetiriam o mesmo clichê. Vale, no entanto, mencionar que o chefe da expedição concebia os americanos como naturalmente semelhantes, pertencentes ao grande grupo tapuia. Constata-se aí, mais uma vez, a lógica de Ferreira, que pretendia identificar cada nação, sem perder de vista a unidade do grupo.

As descrições permitem ainda entender a inserção dos ameríndios na evolução técnica, moral e, sobretudo, física da humanidade. Para Lineu, os americanos eram mamíferos, primatas, regulados pelos costumes. A falta de barba tornava-os monstruosos (Eze, 1997, p. 13). $\mathrm{Na}$ viagem filosófica, os índios foram classificados em "monstruosos por artifício" e "monstruosos por natureza". Os primeiros constituíam os grupos que nasciam perfeitos e deformavam-se segundo os costumes — hábitos considerados bizarros. No grupo, os Cambeba ou Omágua deformavam as cabeças, fazendo-as parecer uma mitra; os Uerequena ou orelhudos rasgavam as extremidades das orelhas; os Miranha possuíam ventas furadas; os Mauá tinham o ventre espartilhado e cingido 
por cascas de árvores; entre os Tucuria, as mulheres tinham o clitóris extirpado. Há também os Jurupixuna ou bocas-pretas e os Gamela. Entre os "monstruosos por natureza", estão os Catauxi ou Purupuru, com mãos e pés malhados de branco; os Cauanaze, uma espécie de pigmeus; e os Ugina, caudados. Os Mura eram ferozes, mordiam as pedras contra eles atiradas, cortavam cabeças, arrancavam os dentes dos mortos e guardavam-nos como troféus. Seus prisioneiros eram logo transformados em escravos, que, em currais, serviam de sustento a seus senhores antropófagos. Seu espírito de vingança era o maior dentre todos (Ferreira, 1972, pp. 133-5).

O presente estudo iconográfico recorreu à totalidade das estampas publicadas pelo Conselho Federal de Cultura em 1971. Procurei, no entanto, restringir a exposição desta análise para se adequar ao formato de artigo. O material foi agrupado conforme a seguinte tipologia: fisionomia, corpo, artefato e quadro.

\section{Fisionomia}

O retrato fisionômico é uma composição estática, destinada a descrever algumas partes da constituição física. Esse tipo de estampa representa somente a cabeça, pescoço e tronco de um indivíduoprotótipo que se torna ícone de uma nação. Para além da tentativa de compor grupos distintos, entre os índivíduos-modelo havia alguns traços físicos comuns. Para Ferreira (idem, pp. 75, 82) o índio era, a princípio, "dócil, tranqüilo e tratável", porém, ao examiná-lo mais de perto, percebiam-se a desconfiança, o ar selvagem e sombrio. "Há, com efeito, em todos eles uma certa combinação de feições e um certo ar, tão privativamente seu, que nele se deve estabelecer a característica de uma figura americana."

A composição das estampas segue este princípio: todos os índios possuem o mesmo semblante. Não há importantes variações na forma da cabeça, face, testa, olhos, orelhas, nariz, boca, pescoço e tronco, exceto aquelas que foram produzidas pelos costumes, ou melhor, artificialmente: "há entre seus corpos, quando não desfigurados, aquela proporção e regularidade em que consiste a perfeição de uma figura americana". Nas estampas, também não se distingue a tonalidade da pele. Nas observações sobre os mamíferos, porém, eles foram descritos como homens cor de cobre ou castanha, cores que variavam apenas na intensidade. Nas serras e montanhas, encontravam-se índios mais alvos, enquanto nas planícies, terras baixas e pantanais as peles eram mais escuras. No entanto, essa diversidade não era definitiva, pois a mudança de espaço poderia clarear ou escurecer a pele. A cor era única para todos os Tapuia; as tonalidades pareciam depender da variação climática e geográfica.

O Tapuia possuía, enfim, uma identidade anatômica. Essa anatomia era, por vezes, conservada, mantendo as características naturais. Mas 
havia também a possibilidade de alterar a forma ou, como destacou Ferreira, deformar faces, orelhas, bocas e narizes. As diferenças, portanto, não se originavam na natureza, provinham dos costumes. As 'deformações' atuavam como identificação dos grupos. As pranchas e as memórias, porém, descrevem muito pouco sobre os costumes indígenas. As descrições textual e visual serviam, sobretudo, para classificar e particularizar grupos; pouco se preocupavam em pormenorizar. Como destacou Sá, os naturalistas teriam de evitar a redundância e o excesso da palavra. As descrições eram, portanto, uma forma de taxionomia, avessas à descrição extensa. Assim, Ferreira identificava e nomeava, recorrendo a dois elementos: formas anatômicas e artesanais - armas, vestimentas e adereços.

Sobre os Cambeba, Ferreira (1974, pp. 50-2) escreveu o seguinte: "Toda essa populosa nação tem cabeças chatas não por natureza, mas sim por artifício: porque logo nascem, as apertam entre duas tábuas, pondo-lhes uma sobre a testa, outra no cérebro; e como se metidas nessa prensa, crescendo sempre para os lados, ficam disformes." Entre as talas e as cabeças metiam almofadinhas, para aliviar a pressão. Desse modo, as crianças suportavam melhor a alteração das cartilagens e ossos cranianos. O formato do crânio atuava como elemento de distinção. Segundo Ferreira, eles recorriam a esse artifício para mostrar que não eram canibais, podendo assim escapar da escravidão. O naturalista os considerou os mais civilizados, pois a cor era mais alva, compondo uma "figura elegante". Eram ainda um verdadeiro prodígio, pois confeccionavam panos de algodão, teciam cobertas e comercializavam-nos.

Para além das características anatômicas, as estampas também representavam adereços, capazes de diferenciar os Tapuia e traçar identidades. O índio Cambeba segura uma flauta de madeira, usa camisa de algodão e colar de dentes, que eram arrancados dos inimigos mortos (Figura 1, ver p. 676). O Mura caracterizava-se pelo chapéu, enfeite labial e cachimbo (Figura 2, ver p. 677). O chapéu possuía somente as abas, confeccionadas com folhas de palmeira ou penas de aves. Os lábios eram furados onde se introduziam pedras oriundas do cérebro do peixe pirarucu, batoques e ossos (Ferreira, 1974, pp. 63, 71, 97, 98). O cachimbo era empregado para tomar "tabaco", denominado paricá. Essa substância provinha do fruto da árvore paricá, que era transformado em pó, torrado e depois depositado em um caracol. Longos ossos de aves serviam como canudos, empregados para inalálo. A substância atuava, segundo o naturalista, como narcótico.

Os Jurupixuna ou bocas-negras (do tupi 'juru' = boca, 'pixuna' = negra) distinguiam-se por suas máscaras. Para produzi-las, picavam o rosto com espinhos da "palmeira pupunha" e pulverizavam, sobre as feridas, cinzas da folha dessa planta. Os enfeites possuíam três formatos: linhas negras e curvas, máscaras na mesma cor em forma retangular e em forma de xadrez, entremeando partes negras e a própria pele. As 


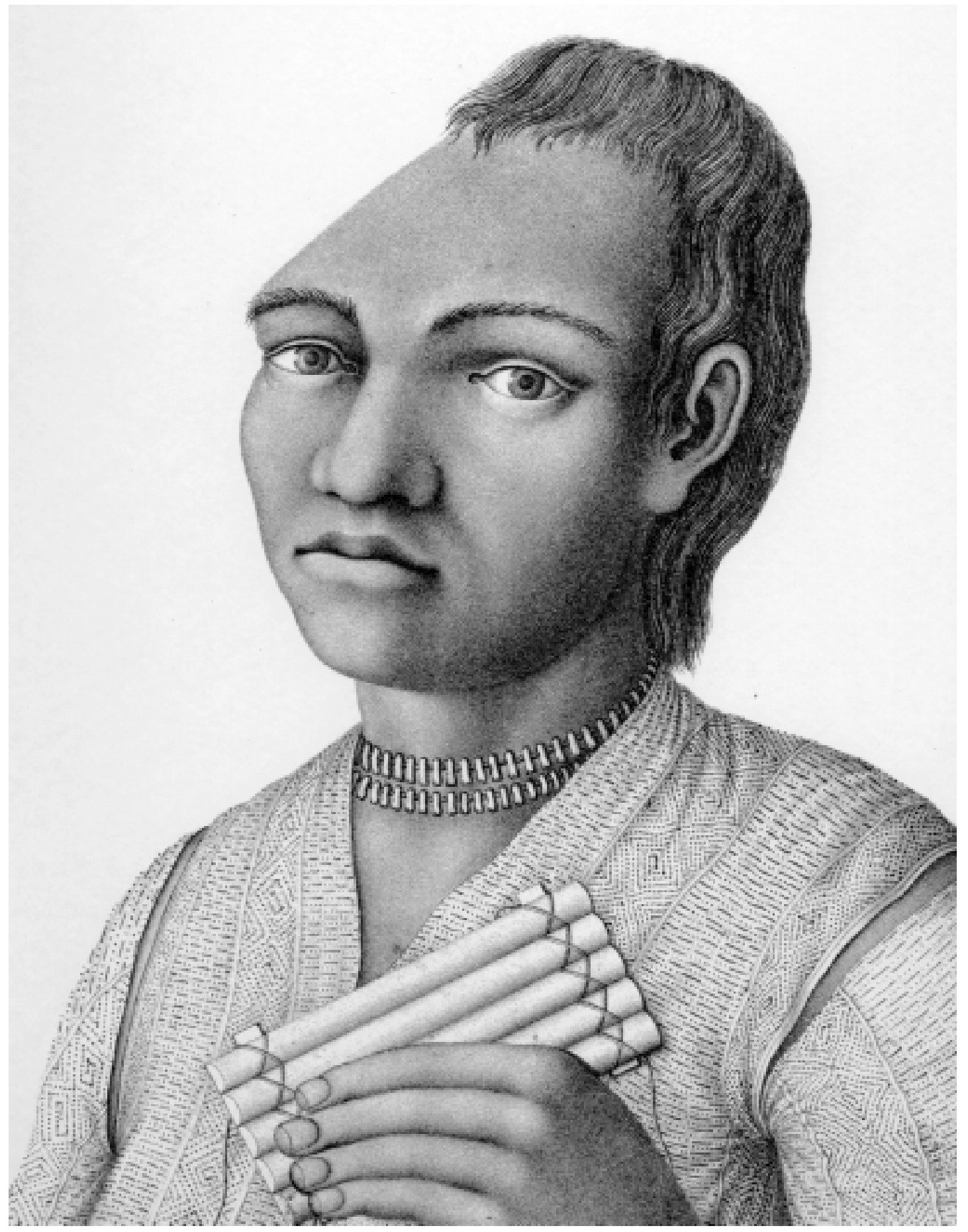

Figura 1 - Índio (Ferreira, 1971, prancha 117). 


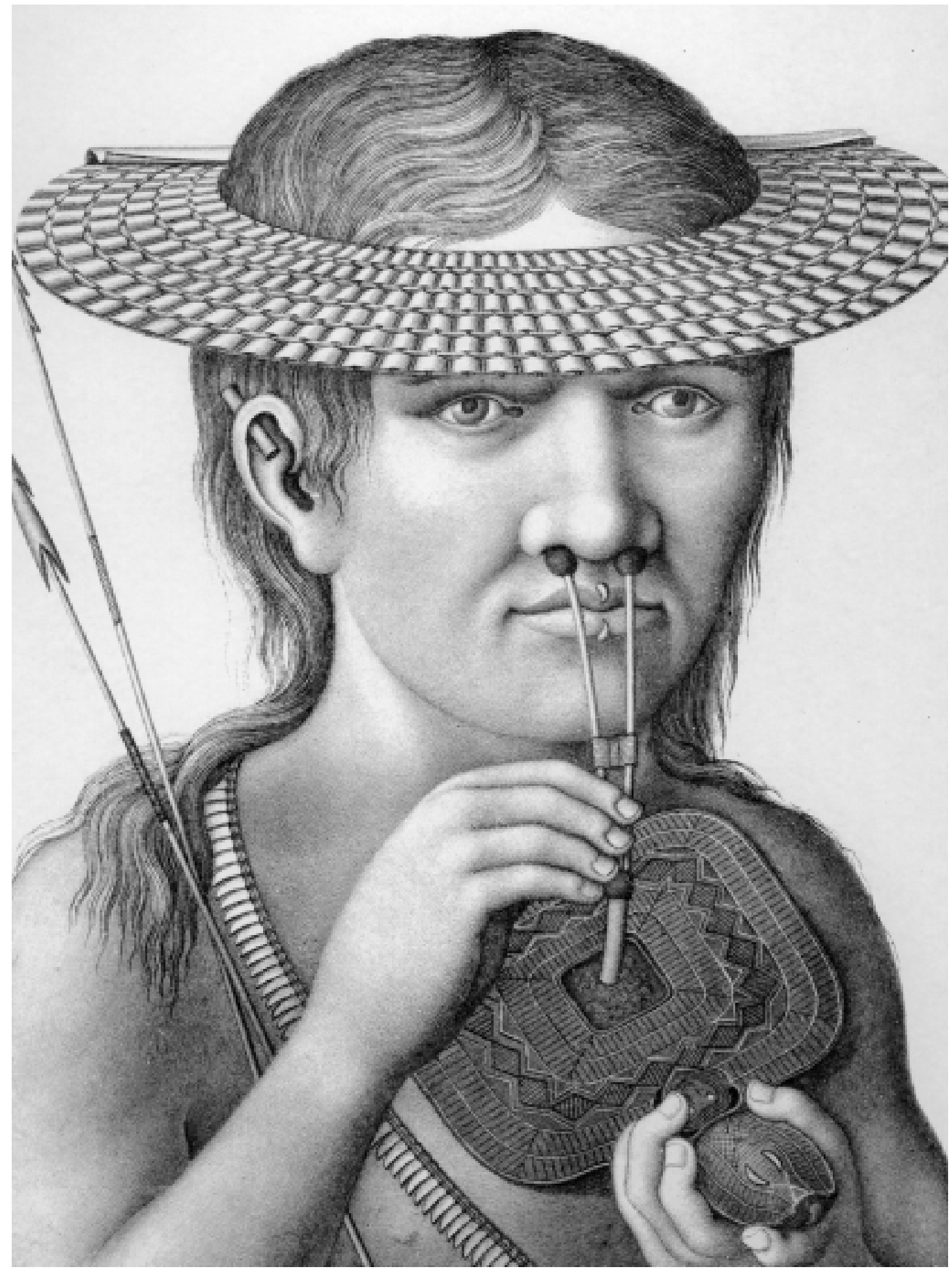

Figura 2 - Índio Mura inalando paricá (Ferreira, 1971, prancha 121). 
linhas negras ligavam a boca à parte inferior da orelha. As máscaras possuíam tamanhos diversos e sua localização no rosto também variava - sobre o nariz ou em torno dos lábios. Os índios ainda portavam zarabatanas e lanças características (Ferreira, 1974, p. 85; 1971, pranchas 104, 106, 108 e 124).

\section{Corpo}

O retrato corporal também é uma composição estática destinada a representar o corpo inteiro. A descrição corporal fornece elementos visuais sobre a proporção entre cabeça, face, testa, orelhas, nariz, boca, tronco e extremidades. Os índios situam-se em uma paisagem padronizada - região árida com árvores, pedras e pequenas plantas rasteiras. Certamente, essa paisagem não é amazônica. A grande contribuição etnográfica dessas pranchas é apresentarem a indumentária dos grupos indígenas, servindo como uma outra forma de classificálos. Alexandre R. Ferreira (1974, p. 72) considerou que a invenção das vestimentas fazia parte do progresso humano. Inicialmente, todos andavam nus; pouco depois, cobriram as "partes vergonhosas" e as demais que necessitavam de proteção contra o tempo e os animais. Recorreram, para tanto, às roupas compostas de folhas, penas e peles de animais. Aos poucos as roupas foram se fechando. De camisetas abertas e sem mangas, tornaram-se mais protetoras e tecidas com fios de lã, linho, algodão ou seda. A arte "ensinou a conhecer, cultivar, recolher, preparar, fiar e tecer cada uma destas substâncias". O retrato corporal aborda, portanto, o mencionado tema e procura inserir os índios nessa evolução.

O progresso da humanidade era ainda verificado no aperfeiçoamento das armas. As primeiras surgiram do acaso, eram simples e grosseiras. Entre os tapuias, ele encontrou artefatos dessa natureza, como as braçangas, "pequenas massas de pau pesado". Para dar maior solidez às lanças, os índios tostaram madeiras ao fogo, obtendo armas mais resistentes, com ossos e pedras pontiagudas na extremidade. Para combater à distância, contavam com arcos, flechas, zarabatanas e palhetas, que foram as primeiras armas de tiro "que então se inventaram" e que, segundo Ferreira (idem, p. 73), "ainda hoje são as únicas que possuem os povos que vivem na infância da sociedade". A coleção e classificação dos artefatos permitiriam ao naturalista traçar uma "história da indústria americana", desde os primórdios até o declínio do estado social e civil. Ao reunir artefatos, o naturalista perceberia os esforços de suas "faculdades ativas", em todos os ramos da indústria, na guerra e na paz. Alexandre Rodrigues Ferreira pretende entender a evolução das comunidades americanas, seja por intermédio das roupas, seja pelas armas, numa concepção de história profundamente vinculada ao progresso técnico. Quando representados, os tapuias exibiam seus atributos técnicos (roupas e 
armas), que atuavam como marcas de uma identidade (particular) e etapa do progresso humano (geral).

Percebe-se, nas estampas, uma classificação: Tapuia nus, seminus e vestidos. Ao dissertar sobre a nudez, o naturalista destacou que os corpos nus não dispensavam máscaras, tinturas e enfeites de braços, pernas, cabelos e orelhas. O clima permitia-lhes a nudez e "a indolência os convida a pouparem-se a toda e qualquer espécie de trabalho, que lhes não for ordenado por uma extrema necessidade" (idem, ibidem, p. 71). Entre os retratados nus, encontram-se o índio Caripuna, Caraya e a índia Miranha (ou Catauixi, conforme legenda da prancha do Museu Bocage). O nu frontal foi evitado: o guerreiro encontra-se representado de lado e com a coxa tapando a genitália, enquanto a índia segura um utensílio que esconde sua intimidade. $\mathrm{O}$ índio Caripuna possui um adorno de cabeça composto de uma coroa, tecida de palhinha e pintada de preto. Ainda sobre a cabeça e por baixo da coroa, há um gorro de algodão que se ajusta como coifa e segue no dorso do índio até os pés (idem, ibidem, pp. 55, 56). Carrega várias armas: bordunas, arco, flechas e uma lança ricamente ornada, armamentos empregados em pelejas corpo-a-corpo e combates à distância. Há ainda um objeto semelhante ao maracá Tupinambá (Figura 3 ver p. 680). Ferreira comentou que os Caripuna possuíam um instrumento musical, uma espécie de chocalho escondendo sementes ou seixos no interior, que produziam sons quando sacudidos.

Entre os Tapuia seminus, encontravam-se os índios Miranha, Maua e Uaupé (ou Curutu, conforme legenda da prancha do Museu Bocage). De tez clara, o Miranha (Figura 4, p. 681) apresenta uma corda em torno da cintura, onde se ata uma pequena tanga de tecido. Seus artefatos característicos são a zarabatana, as penas presas em orifícios artificialmente produzidos nas narinas e um cilindro onde acondicionavam peixe seco. Vestimenta semelhante cobre o índio Uaupé/ Curutu, que carrega flechas, lanças e uma pequena borduna. Uma touca colorida é a sua maior identificação. O retrato corporal do Maua é, sem dúvida, singular. Sua identidade foi construída por intermédio de uma 'deformidade física' e pelos artefatos — roupas e armas. Eles andavam "espartilhados ao uso das damas da Europa", com enfeite composto de lâminas de madeira avermelhada, que, por ser apertado, comprimia o ventre, deformando sua anatomia, deixando-os de cintura fina. Uma pequena tanga, colorida como o espartilho, cobria o pênis e os testículos. No pescoço, enfeitavam-se com um colar de contas de moçambique, na cor preta, que descia até a cintura. As armas são arco, flechas e uma espécie de remo, que se assemelha a uma grande e longa folha (Ferreira, 1974, pp. 31, 32).

Enfeites e deformidade corporal também caracterizavam os Uerequena (ou Warakena). Além de portar penacho colorido e tanga, esse grupo tinha o costume de perfurar as extremidades inferiores das orelhas, onde introduziam pequenos tornos de pau ou flechas. Os 


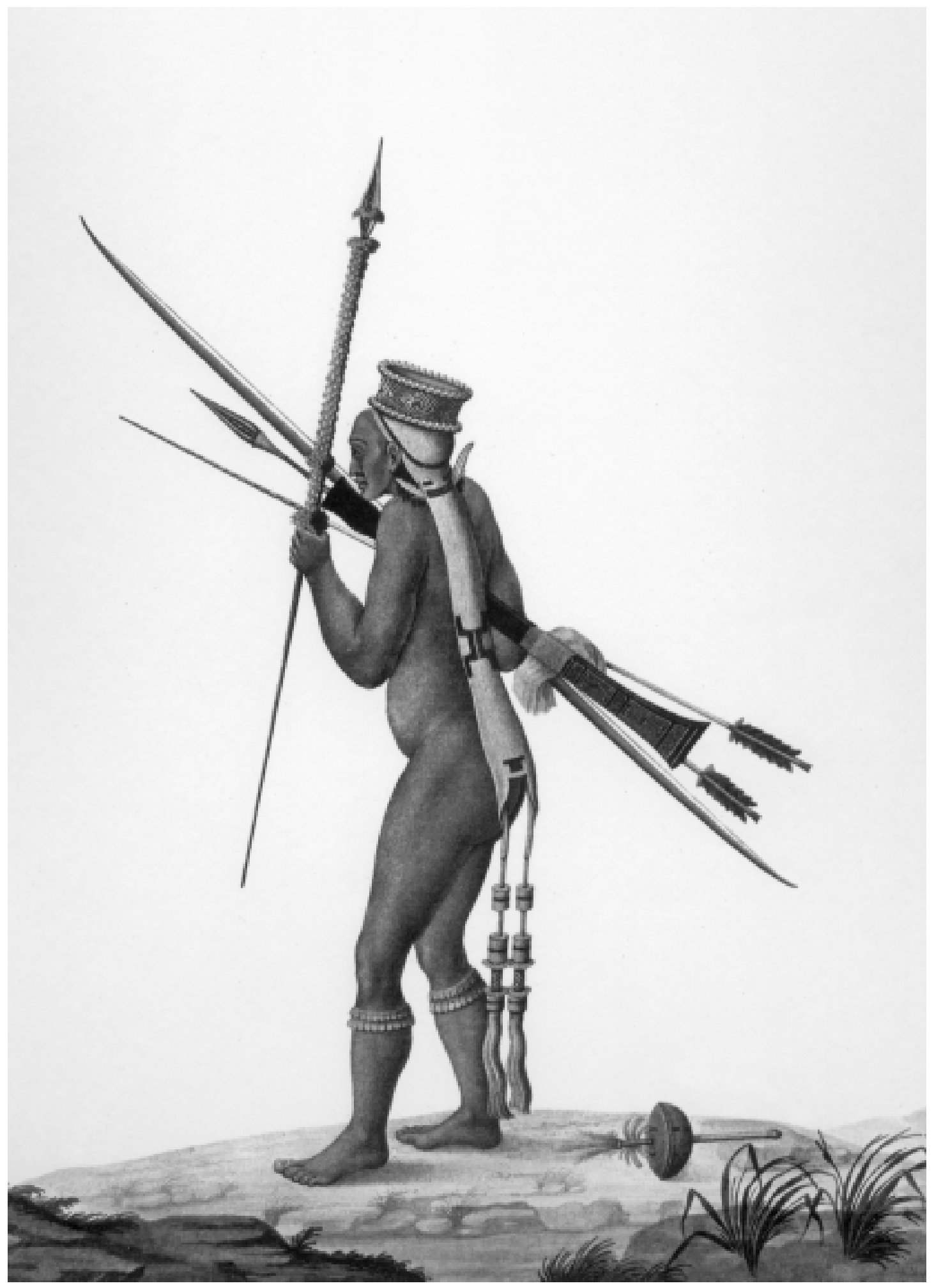

Figura 3 - Índio Caripuna (Ferreira, 1971, prancha 122). 


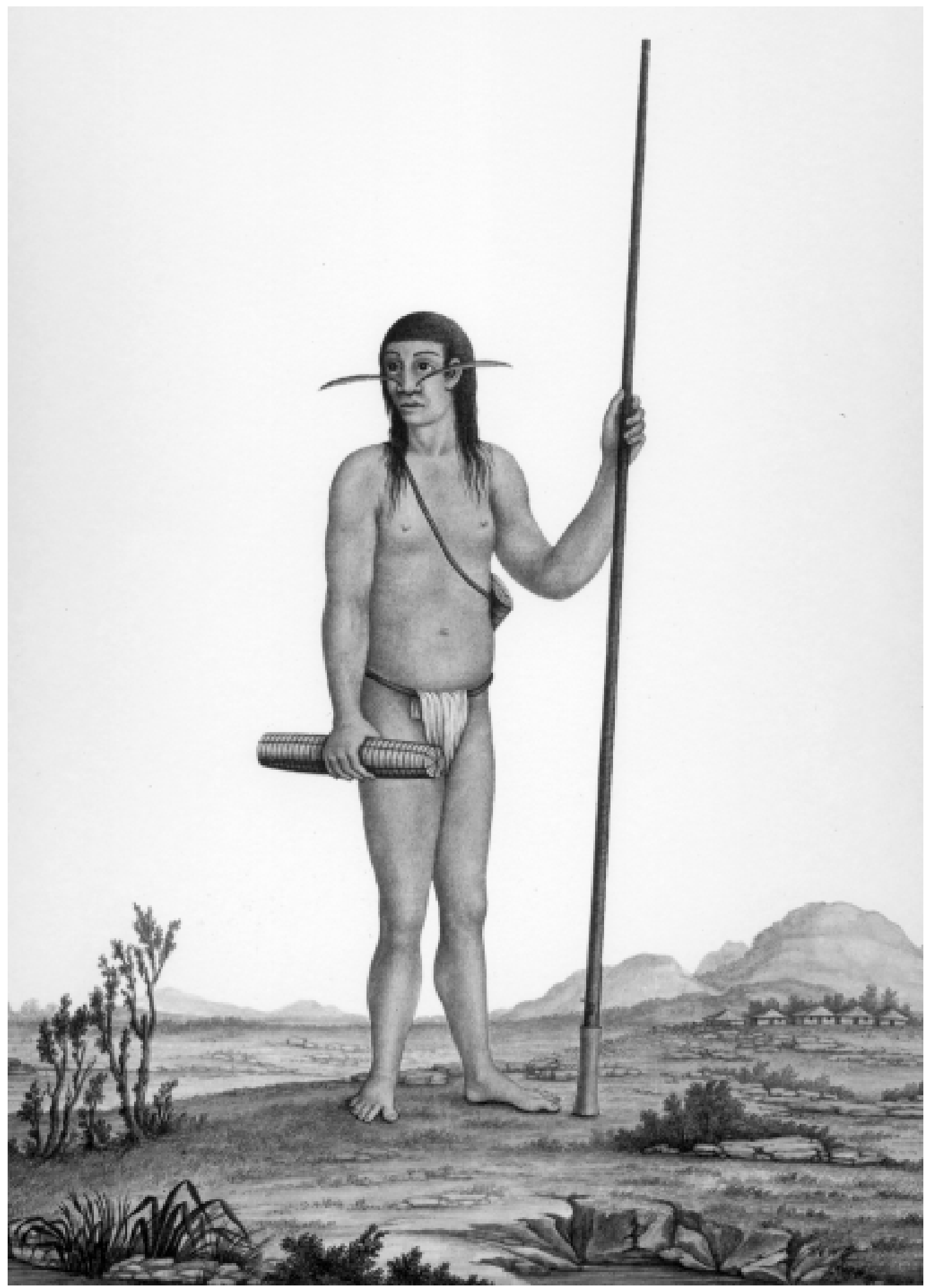

Figura 4 - Índio Miranha com zarabatana e cargaz (Ferreia, 1971, pranchas 114, 101 e 111). 
lóbulos iam se "dilatando cada vez mais, à proporção que lhe introduzem corpos mais volumosos, até chegarem ao ponto de trazerem nelas molho de palha; de sorte que, em alguns daqueles indivíduos lhes descem até aos ombros as extremidades das orelhas" (Ferreira, 1974, pp. 69, 71). O naturalista considerou esses sinais ou deformidades como industriais, ou melhor, uma ação humana sobre a natureza. Os gentios, generalizou, procuravam aperfeiçoar seus enfeites e possuíam uma "inclinação natural a alterar as formas naturais de seus corpos".

Em Casal de índios do Rio Branco, o riscador compôs um par, em vez de um indivíduo. Essa composição era recorrente nos "livros de hábitos" que remontam ao século XVI (Raminelli, 1999). A representação do homem e da mulher servia para caracterizar os gêneros: seus costumes, habilidades e vestimentas. Nessa estampa, o contraste entre o feminino e o masculino é marcante. Ambos estão seminus. Uma pequena tanga de tecido branco cobre a genitália do índio, que porta ainda sandálias e um colar. A índia usa uma tanga decorada com desenhos geométricos, presa à cintura por um feixe de fios. Os seios estão desnudos e uma pequena faixa cobre a parte superior dos braços, os joelhos e tornozelos, mas os pés estão descalços. Segura uma cesta e uma pequena ave verde, talvez um papagaio. O homem carrega armas que não eram comuns entre os índios da Amazônia, e certamente originavam-se do comércio entre nativos e holandeses que freqüentavam o extremo norte da Amazônia. Encontram-se aí rifle e espada de metal. O comércio entre holandeses e índios se realizava na troca de manufaturados por gêneros de produção natural e artesanal. Esse escambo também envolvia escravos indígenas que, capturados, serviam como mercadorias de troca. O casal poderia ser Caripuna, Macuxi e Paraviana, que recebiam dos holandeses armas, pólvora, panos, espelhos e facões em troca de escravos (Ferreira, 1994, pp. 122-34; Farage, 1991, pp. 101-6; Hartmann, 1991, p. 116). A estampa, portanto, além de marcar a identidade desse grupo, destaca as fronteiras entre os gêneros: o homem carrega armas e tangas de tecidos, que representam a proximidade entre os guerreiros e os colonizadores (holandeses); a mulher carrega uma ave e um cesto, vestindo-se de tanga, confeccionada com palha, talvez. Não há, porém, indícios de contatos entre a índia e os europeus; esse intercâmbio, por certo, pertencia ao mundo masculino (Ferreira, 1971, prancha 105).

O índio Cambeba distinguia-se por suas roupas. As túnicas eram confeccionadas com algodão e tingidas de azul. O grupo produzia também cobertas (tapuiranas) de vários matizes e panos de uso doméstico. Para tanto, plantavam algodão; as mulheres preparavam os fios e fabricavam-nos, segundo Ferreira, com admirável arte. Os vestidos, no entanto, "não tinham artifício algum"; não eram "mais que um pano lançado para diante, e para trás, com um buraco por onde introduziam a cabeça, e dois nos lados, para os braços" (Ferreira, 1974, p. 51). Os Cambeba aprenderam também a fabricar goma ou resina elástica (leite 
de seringa), que servia para produzir botas, sapatos, chapéus e demais objetos impermeáveis. Demonstravam ainda conhecer armamentos de tiro, pois seguravam flechas e palhetas. O instrumento bélico arremessava-as a grandes distâncias, com admirável destreza e precisão (Hartmann, 1991, p. 116).

Além de evitar a nudez, os Cambeba possuíam as melhores técnicas para produzir tecidos e armas, razão para Ferreira considerá-los os mais civilizados entre os gentios. Os índios do Rio Branco, em contrapartida, ocupavam estágios inferiores na escala evolutiva traçada por Ferreira, mas desfrutavam de armas e tecidos europeus. O contato permitiu-lhes um salto tecnológico e vantagens nas disputas intertribais. A posse de armas de fogo e instrumentos de ferro tornava-os superiores, capazes de aprisionar os inimigos e reduzi-los à submissão. Os escravos eram a pedra de toque no comércio com os holandeses, que ameaçava o controle lusitano sobre o território ainda pouco explorado pelos colonizadores luso-brasileiros. O escambo provocava, enfim, o progresso técnico que escapava ao controle dos portugueses.

\section{Artefato}

No acervo da Viagem Filosófica, encontram-se estampas que representam a cultura material dos Tapuia. Ao contrário dos retratos, elas não se destinavam apenas a identificar os grupos indígenas. Havia outras finalidades para se reunir e reproduzir graficamente o material coletado por Ferreira ao longo da jornada. Esses objetos eram enfeites e utensílios empregados em ritos, instrumentos musicais, cerâmicas, armas, canoa e maloca. A lógica dessa classificação era, sobretudo, utilitarista. No diretório pombalino, ficara estabelecido que os índios deveriam se inserir na colonização como homens livres, exercendo atividades agrícolas, artesanais e comerciais. As mercadorias permitiriam, enfim, o incremento do comércio colonial e a civilização dos índios da Amazônia. Ao refletir sobre esses artefatos, Ferreira tocava em pontos da maior importância: comprovava a "rudimentar" capacidade indígena de produzir e avaliava a evolução das técnicas. Como agente do colonialismo e naturalista, o viajante procurava tanto dinamizar a economia regional, quanto traçar o perfil das técnicas nativas para compor a "história da indústria americana", desde seus primórdios até o "declínio de seu estado social e civil".

Para Ferreira, esses utensílios mediam o grau de civilidade das comunidades indígenas. Quanto maior o aperfeiçoamento desse material, mais civilizados eram os índios. Se produziam tecidos, punham-se contra a nudez; se construíam armas, eram inimigos temerosos; se dominavam técnicas náuticas, eram importantes aliados dos colonizadores no deslocamento pelo território e coleta das drogas do sertão. Nas memórias escritas por Ferreira, torna-se evidente o valor econômico dessas habilidades indígenas: potes e barcos poderiam gerar 
recursos para as comunidades, caso fossem vendidos, tanto na metrópole quanto na colônia. As armas possuíam também valor estratégico, sendo indispensáveis para a manutenção das fronteiras. $\mathrm{Na}$ 'Memória sobre as cuias', Ferreira descreveu todo o processo de confecção desses utensílios, desde a colheita da matéria-prima até os retoques finais. Debruçou-se ainda sobre sua utilidade e aceitação entre os Mazombo. Para finalizar, escreveu: "Veja-se a memória sobre as salvas de palhinha e pacarás, em que aponto a razão por que todas estas curiosidades da indústria das índias lhes não são tão lucrativas, como parece que deveriam ser" (op. cit., p. 39). Assim, as pranchas não foram concebidas apenas como ciência, mas como imagens de mercadorias que deveriam ativar o comércio colonial e integrar as comunidades nativas na 'civilização', como planejara o diretório pombalino.

A "história da indústria americana" seria construída com a coleta e ordenação de artefatos. As armas foram então agrupadas conforme o tipo de combate: de um lado estavam as bordunas e machados para as disputas corporais, enquanto os embates à distância exigiam instrumentos mais elaborados, com dispositivos aerodinâmicos, como lanças, zarabatanas, palhetas, arco e flechas representadas com uma variedade de pontas. Cerâmicas, máscaras, ornamentos de cabeça, enfeites de palha e penas foram também considerados subsídios para avaliar a inserção dos índios na evolução da humanidade (Figura 5).

Sobre a estrutura da maloca Curutu, o naturalista-viajante destacou a forma circular e os compartimentos internos, divididos entre áreas

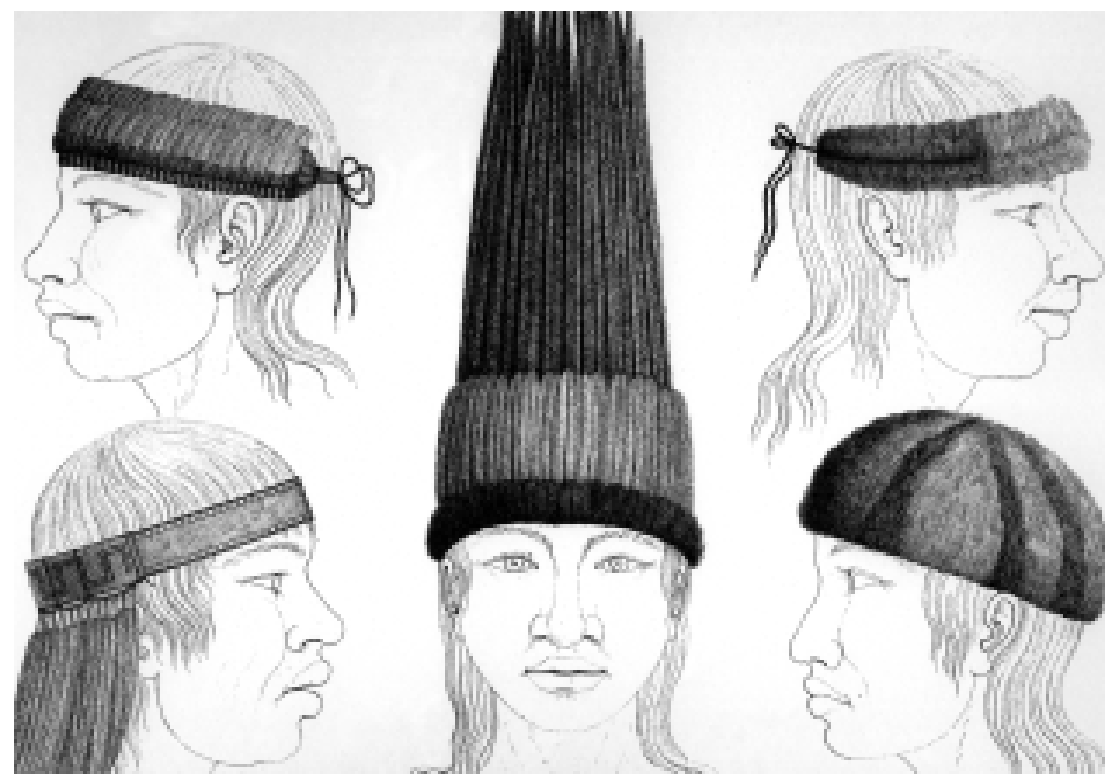

Figura 5 - Ornamentos de cabeça de índios da Amazônia (Ferreira, 1971, pranchas 129, 130, 131-35, 137 e 139). 
comuns e áreas familiares. O sistema de circulação de ar e de iluminação dominava a parte superior da construção. Para evitar aves e morcegos, os índios inseriram nas aberturas uma engenhosa peça que procurava imitar uma serpente. Com o vento, folhas retorcidas de pindoba imitavam o ziguezague de uma cobra, impedindo os animais de entrar no recinto (Ferreira, 1971, pranchas 126, 127). As etapas da construção de canoas também foram representadas. Inicialmente, punham fogo no interior de um tronco, depois retiravam os excessos para permitir a instalação de compartimentos e assentos no barco. A capacidade de subordinar a natureza às necessidades humanas era um meio de avaliar a civilidade dos povos.

Apesar do domínio apresentado sobre alguns fenômenos da natureza, Ferreira (1972, pp. 86-90) considerou que a racionalidade indígena não era "mais iluminada nem mais previdente que o instinto dos animais". Em alguns momentos, porém, deixavam "entrever uma inteligência, ainda que embrionária, capaz de se desenvolver". A poderosa "mola das ações humanas", a ambição, era inerte, pois viviam na indolência e a felicidade consistia em não trabalhar. Quando a fome os perseguia, satisfaziam-se com qualquer raiz e animais, disponíveis na natureza. Não havia, entre eles, previsão para o futuro. Como os requisitos naturais eram parcos, comentou Ferreira, seus esforços espirituais e corporais estavam na mesma proporção. Recorrendo a vários testemunhos, tachou os americanos de "estúpidos e indolentes", inserindo-se entre os detratores da América.

$\mathrm{Na}$ sociedade ocidental setecentista, o controle sobre o meio, a capacidade de construir e alterar matérias-primas tornaram-se elementos essenciais para avaliar e classificar os povos. Os americanos não dominaram a natureza hostil, nem souberam vencer, submeter e convertê-la em seu benefício. Para Buffon, a umidade do continente americano era adversa à civilização e propícia aos répteis, seres de sangue frio. Comparados aos europeus, eles eram menos inteligentes, menos sensíveis: "São como bebês raquíticos, irreparavelmente indolentes e incapazes de qualquer progresso mental" (Gerbi, 1996, p. 58). Leitor de Buffon, o naturalista Alexandre R. Ferreira procurou comprovar as teses do famoso naturalista e estabeleceu que a preguiça e a indolência eram responsáveis pelo atraso da Amazônia. Nesse sentido, o compêndio dos artefatos indígenas era a forma de inserir essa produção no comércio colonial e tirar os americanos da inércia. A intervenção colonialista, portanto, era forma de integrar os americanos nos rumos da 'civilização' e estimular sua inteligência ainda embrionária.

\section{Quadro}

O quadro, segundo Buffon, pretendia captar a dinâmica, o movimento dos fenômenos que não foram contemplados nas 
descrições estáticas. Os índios Guaikurú foram representados em plena ação, em um ambiente de rio e arvoredos. A cena descreveos atravessando um rio e controlando cavalos. Ali encontram-se crianças, homens e mulheres nus ou cobertos por pequenas tangas. Os cavalos possuem arreios e rédeas, demonstrando aperfeiçoamento no controle da natureza (Figura 6). A prancha procurou simular o cotidiano indígena: a interação entre os indivíduos, os animais e o meio ambiente. Atua, portanto, como simulacro da realidade, onde existem várias ações simultâneas que buscam imitar a realidade. Essa composição não se encontra nas demais pranchas, que representam os índios de forma estática. Se nestas os corpos, os artefatos e as indumentárias constituem os principais temas, nas pranchas dinâmicas encontram-se o movimento e o cotidiano nas comunidades indígenas.

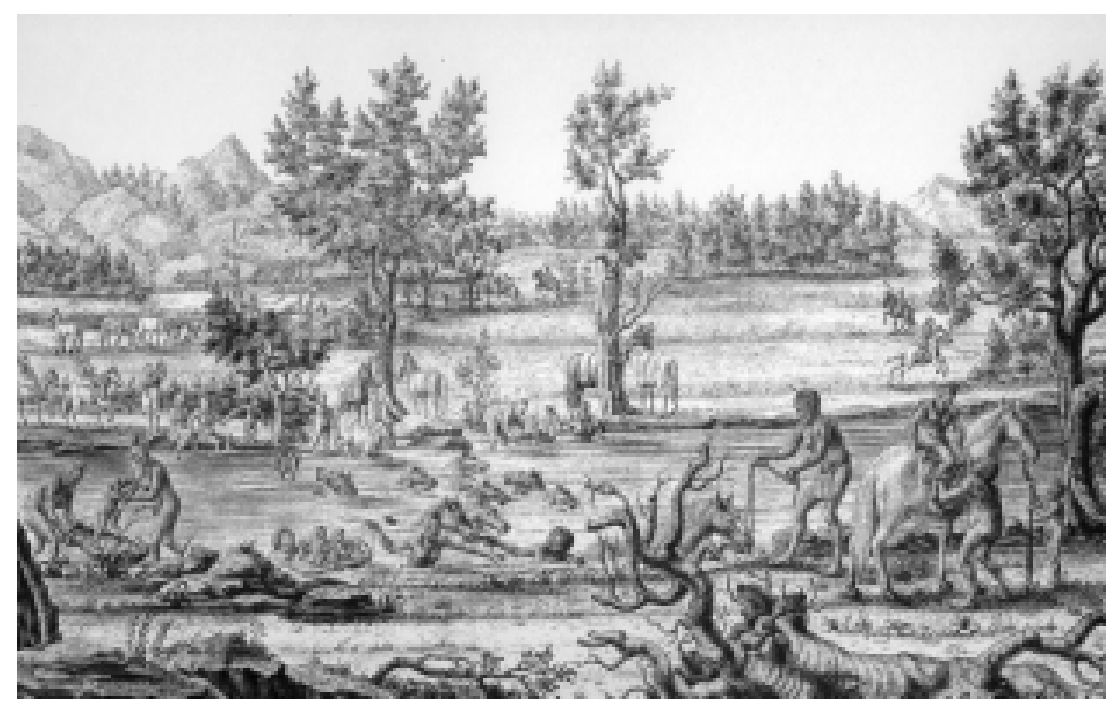

Figura 6 - Acampamento Guaikurú à beira de rio: cena totalmente idealizada (sem autor). Nanquim sobre papel 19,2 × 30,5cm (Biblioteca Nacional do Rio de Janeiro).

Na memória sobre esse gentio, Ferreira (1974, p. 79) fez o seguinte comentário: "A sua vida é de corso, tanto em terra como pelos rios; com a diferença que, em terra, andam montados a cavalos, donde lhes vem o nome de cavaleiros; e pelos rios navegam em ligeiras canoas que remam com incrível celeridade." Entre seus bens, os mais apreciados eram escravos, armas e cavalos, estes obtidos por intermédio de furtos aos espanhóis.

Seus prisioneiros eram degolados e as cabeças exibidas como troféus. Naquele momento, os Guaikurú eram índios reduzidos. Antes da 'pacificação', porém, assaltavam os caminhos, viviam na fronteira e se aliavam aos espanhóis. A submissão aos portugueses assegurou o comércio interno e a segurança da região das minas, antes 
ameaçados. Infestavam os rios Cuiabá, São Lourenço ou Porrudos, Embotetéu ou Mondego e Taquari.

Diferindo das demais estampas, encontram-se aí homens, mulheres e crianças que se movimentam e interagem. As crianças são transportadas em pequenas balsas, o que permite constatar cuidado e organização familiar, características nem sempre presentes nas representações dos índios. No primeiro plano, um índio auxilia uma mulher a descer do cavalo, após atravessar o rio, enquanto uma criança segura o animal. A cena possivelmente demonstra a interação entre os componentes de uma família. O quadro fornece, portanto, elementos para reflexão sobre a vida social e, sobretudo, a 'constituição moral' desse gentio. O naturalista dissertou longamente sobre o tema e apontou as principais características da relação familiar dos Tapuia.

Destacavam-se pela fidelidade conjugal: as mulheres estavam sempre com os maridos. Os ajuntamentos entre homens e mulheres eram realizados sem regras, como o "matrimônio dos animais": "Amam-se ternamente e os maridos como se disse, zelam quando podem, a fidelidade conjugal." De modo geral, a mulher era mais escrava do que esposa, ficando boa parte das tarefas a seu encargo. Nas comunidades, aceitavam tanto a monogamia, quanto a poligamia: "O país é fértil e abundante, de maneira que não exige nenhum cuidado em relação a uma numerosa família quando assim pedem as instituições." Contrariando as teses de Buffon, não se mostravam frios para o amor, pois nem mesmo a fome, as pestes e guerras enfraqueciam o interesse sexual.

Como revela a estampa, o amor entre pais e filhos pequenos era irrefutável. "Esse amor", considerou Ferreira (1972, pp. 96, 97), "dura tanto como o de qualquer animal." Depois que cresciam não mais havia intervenção paterna ou materna sobre os comportamentos. O amor familiar, porém, era debilitado e enfraquecido pelos costumes: "Tudo aquilo que entre os povos civilizados só se faz com grande recato, em ordem de respeito e decência, eles, sem alguma malícia, praticam um ao lado do outro."

Os índios eram nômades, vagando de um alojamento para outro, carregando suas mulheres e filhos, como demonstra a prancha. Em média, tinham altura de oito palmos e meio. "Tapuia que até agora tenho visto porém, todos eles eram igualmente espadaúdos e quadrados, com os peitos largos e fornidos, o ventre plano, o dorso e os braços musculosos" (Ferreira, 1974, p. 78).

A habitação temporária, o tijupar, encontra-se ao fundo da composição. Quatro estacas e um telhado de palha abrigam as redes de dormir. Próximo há uma cena de caça, onde dois índios a cavalo pretendem laçar um animal. Do lado esquerdo, mais dois indivíduos, munidos de lança, demonstram também procurar animais.

O quadro dos Guaikurú, enfim, é uma descrição do movimento, da dinâmica capaz de representar tanto o controle sobre animais, 
quanto fornecer elementos para avaliar a vida material, social e a constituição moral desse gentio.

\section{Conclusão}

As viagens do século XVIII inauguram uma era de descobertas dos interiores, e a interiorização torna-se uma meta para manter a conquista. Se, inicialmente, os europeus dedicaram-se ao conhecimento dos contornos dos continentes, rotas marítimas e ligações entre oceanos, no Setecentos partiram para o domínio e controle sobre os recursos naturais localizados no interior dos territórios. Ocorreu, portanto, uma mudança na concepção que a Europa tinha de si mesma e de suas relações globais. Os naturalistas tiveram participação intensa nesse processo, concebendo textos descritivos especializados que, por vezes, continham nomenclaturas e taxionomias. Os relatos de viagem tornaram-se aprimorados e dedicados aos diferentes ramos do conhecimento. Os sistemas classificatórios do século XVIII, sobretudo depois de Lineu, tinham a tarefa de localizar as espécies do planeta, extraindo-as de seu nicho original, onde reinava o caos, e enquadrá-las em um sistema ordenado segundo as normas científicas.

Os naturalistas atuavam como homens de ciência, recorrendo à neutralidade para produzir conhecimento. Como bem percebeu Mary Pratt (1993), eles desempenhavam simultaneamente funções de cientistas e agentes imperiais, auxiliando a expansão da Europa. Por intermédio da história natural, aprendiam-se o valor e a importância das comunidades e regiões percorridas. Desse modo, as memórias, as pranchas e as espécies coletadas demonstravam as potencialidades da exploração comercial. A ciência atuava como "descrição exata de tudo" e funcionava como um espelho rico e multifacetado, no qual toda Europa pôde projetar a si mesma como construtora de processo planetário em expansão. Em nome da ciência, os naturalistas atenuavam a competição e violência provocadas pela expansão comercial, política e pelo domínio colonial. A sistematização da natureza e dos povos representava não apenas um discurso sobre os mundos não-europeus, mas um discurso urbano, burguês e letrado, sobre os mundos iletrados e rurais, que atuavam não somente no além-mar, mas sobre os campos europeus, transformando-os segundo a lógica do capital.

As pranchas da viagem filosófica possuem essa racionalidade. Constituem uma produção artística e científica munida de uma lógica colonial, destinada a classificar e transformar a natureza e as comunidades indígenas em bens para manutenção e exploração. A Coroa deveria preservar o patrimônio colonial, incrementar a indústria para atender as demandas do comércio com o Brasil e superar o atraso da agricultura, fosse na metrópole, fosse nas colônias. Essas reformas produziriam 
uma economia diversificada e capaz de consolidar os laços coloniais, em face das ameaças expansionistas dos comerciantes britânicos.

Nas estampas da viagem filosófica tornam-se evidentes os vínculos entre interesses comerciais, políticos e científicos. Os desenhos procuravam expressar três aspectos básicos das comunidades indígenas: evolução técnica - a capacidade de produzir artefatos e de inseri-los no comércio colonial eram indícios de civilidade. A 'indústria americana' deveria ser controlada pelos colonizadores luso-brasileiros; do contrário, o controle territorial estaria ameaçado; identidades culturais — os traços culturais eram formas de identificar as nações. Por intermédio das deformidades físicas, vestimentas e artefatos, o naturalista promoveu uma classificação que pretendia não apenas particularizar as nações, mas também indicar o seu grau de evolução técnica; composição física - os Tapuia possuíam identidade corporal e, naturalmente, as mesmas estruturas anatômicas que comprovavam a unidade entre os povos da Amazônia.

\section{REFERÊNCIAS BIBLIOGRÁFICAS}

Domingues, Ângela 1992

Domingues, Ângela 1991

Eze, Emmanuel C. (org.)

1997

Farage, Nádia

1991

Faria, Miguel

Faria, Miguel 1992b

Ferreira, Alexandre Rodrigues e Wilkens, Henrique João 1994

Ferreira, Alexandre Rodrigues 1974

Ferreira, Alexandre Rodrigues
'Olhares sobre o Brasil nos séculos XVII e XVIII: os pintores holandeses e portugueses'. Em Brasil, nas vésperas do mundo moderno. Lisboa, CNPCDP.

Viagens de exploração geográfica na Amazônia em finais do século XVIII: politica, ciência e aventura. Lisboa, Instituto de História de Além-Mar.

Race and the Enlightenment.

Londres, Blackwell.

As muralhas do sertão: os povos indigenas no Rio Branco e a colonização. Rio de Janeiro, Paz e Terra/ANPOCS.

'O desenho em viagem'.

Oceanos, 9, pp. 65-79.

'Os estabelecimentos artísticos do Museu do Palácio Real da Ajuda e a viagem filosófica de Alexandre Rodrigues Ferreira'. Em Carlos Almaça et alii, Viagem filosófica de Alexandre Rodrigues Ferreira. Ciclo de conferências, Lisboa, Academia da Marinha.

Relatos da fronteira amazônica no século XVIII.

Em Marta Amoroso e Nádia Farage (orgs.). São Paulo, NHII/USP/Fapesp.

Viagem filosófica pelas capitanias do Grão-Pará, Rio Negro,

Mato Grosso e Cuiabá. Memórias: antropologia.

Rio de Janeiro, Conselho Federal de Cultura.

Viagem filosófica pelas capitanias do Grão-Pará, Rio Negro,

Mato Grosso e Cuiabá. Memórias: zoologia/botânica.

Rio de Janeiro, Conselho Federal de Cultura. 
Ferreira, Alexandre Rodrigues

1971

Foucault, Michel s. d.

Gerbi, Antonello 1996

Hartmann, Tekla 1991

Martinelli, Gustavo 1992

Mayr, Ernest 1998

Pratt, Mary L. 1993

Raminelli, Ronald 1999

Reynaud, Denis 1990

Rudnick, M. J. S. 1976

Sá, José António de 1783

Stafford, Barbara M. 1984

Vandelli, Domenico 1779

Vanzolini, P. E. 1996
Viagem filosófica pelas capitanias do Grão-Pará, Rio Negro, Mato Grosso e Cuiabá. Iconografia. Rio de Janeiro, Conselho Federal de Cultura, vol. 1.

As palauras e as coisas.

Lisboa, Portugália.

O Novo Mundo: história de uma polêmica - 1750-1900.

São Paulo, Companhia das Letras.

'Perfil de um naturalista'. Em Memória da Amazônia: Alexandre Rodrigues Ferreira e a viagem filosófica. Coimbra, Museu e Laboratório Antropológico/ Universidade de Coimbra.

'Aspectos botânicos da Viagem filosófica (1792-1991)'.

Em Viagem filosófica: uma redescoberta da Amazônia. Rio de Janeiro, Index.

O desenvolvimento do pensamento biológico.

Brasília, EdunB.

Imperial eyes and transculturation.

Londres, Routledge.

'Habitus canibal'. Em Paulo Herkenhoff, O Brasil e os holandeses. Rio de Janeiro, Sextante.

'Pour une théorie de la description au $18^{\text {ème }}$ siècle'. Dix-buitième Siècle, 22, pp. 347-66.

'The emergence of a visual language for geological science'. History of Science, 14, pp. 149-96.

Compendio de observaçoens que se tórnão o plano da viagem política, e filosófica, que se deve fazer dentro da patria. Lisboa, Officina de Francisco Borges de Sousa.

Voyage into substance.

Cambridge, MIT.

'Viagens filosóficas ou dissertação sobre as importantes regras que os filósofos naturalistas nas suas peregrinações devem principalmente observar'. Lisboa, Academia das Ciências, manuscrito 405, série vermelha, p. 9.

'A contribuição zoológica dos primeiros naturalistas viajantes do Brasil'. Revista USP, 30, pp. 190-238.
Recebido para publicação em agosto de 2000. Aprovado para publicação em fevereiro de 2001. 